\title{
УДК: 336.7:657
}

\section{ОСОБЛИВОСТІ ОБЛІКУ ТА ОРГАНІЗАЦЇ̈ ОПЛАТИ ПРАЦІ У СФЕРІ ПРОЕКТНОГО БАНКІВСЬКОГО МЕНЕДЖМЕНТУ}

\author{
Андріана Суручану'; Валерія Жарнікова ${ }^{2}$; \\ Олена Соболєва-Терещенко ${ }^{1}$
}

\author{
${ }^{1}$ Київський університет імені Бориса Грінченка, Київ, Украӥна \\ ${ }^{2}$ Київський національний торговельно-економічний університет, \\ Київ, Украӥна
}

\begin{abstract}
Резюме. Присвячено дослідженню сучасного стану та тендениій розвитку проектного банківського менеджменту в Украӥні. Розглянуто й доведено, щзо управління проектами являс собою окремо розвинену область менеджменту зі своєю методологією, професійними знаннями, методами та інструментами. Проаналізовано рівень середньої зарплатні «Менеджер проектів» в Украйні у 2020 роиі. Проведено порівняльну характеристику зазначеного вище показника з аналогічними показниками одинадияти краӥн Свропейського союзу. Виявлено, щзо рівень середньої зарплатні «Менеджер проектів» 8 Украӥні значно відстає від зарплат проектних менеджерів в Швейцарії, Німеччині, Нідерландах та іниих країнах Європейського союзу. Систематизовано основні варіанти реалізації банківського проекту. Встановлено, щчо для успішної реалізачії будь-якого проекту в банку потрібно побудувати ефективну систему оплати праці проектного офісу. Визначено класифікацію витрат у рамках упровадження проектів y банках. Запропоновано витрати в рамках упровадження проектів у банках структурувати у три групи: ијільові витрати, загально-проектні витрати, загально-банківські витрати. Результати досліджень наведено у вигляді таблиць та графічних інтерпретацій. Розкрито варіанти вдалої реалізації банківського проекту та висвітлено кілька методів системи нарахування оплати праці у вигляді заохочень. 3 метою стимулювання учасників проекту протягом усього його життєвого ичику обтрунтовано доиільність застосування акордно-преміальної системи оплати праџі в банківському проектному менеджменті. Запропоновано два варіанти організації виплати заробітної плати при акордно-преміальній системі оплати праці залежно від тривалості банківського проекту. Висвітлено особливості обліку розрахунків 3 персоналом по заробітній платі в проектному банківському менеджменті, наведено бухгалтерські проводки, пов'язані з формуванням облікової інформачії про розрахунки, щзо виникають між учасниками проекту в банках. Розроблено ряд рекомендаційних заходів розвитку проектного банківського менеджменту.

Ключові слова: банк, бухгалтерський облік, упровадження проектів, заробітна плата, система оплати працุi.
\end{abstract}

\section{FEATURES OF ACCOUNTING AND ORGANIZATION OF LABOR REMUNERATION IN THE FIELD OF PROJECT BANKING MANAGEMENT}

\author{
Andriana Suruchanu'; Valeriia Zharnikova ${ }^{2}$; \\ Olena Sobolieva-Tereshchenko ${ }^{1}$
}

${ }^{1}$ Borys Grinchenko University of Kyiv, Kyiv, Ukraine

${ }^{2}$ Kyiv National University of Trade and Economics, Kyiv, Ukraine

Summary. The paper is devoted to the investigation of the current state and trends of the project banking management in Ukraine. It is stated and proved in this paper that project management is a separately developed 
area of management with its own methodology, professional knowledge, methods and tools. The average salary level of "Project manager» in Ukraine in 2020, is analyzed in this scientific paper. Comparative analysis of the above mentioned indicator with similar indicators of eleven European Union countries is carried out. It is defined that the average salary level of «Project manager» in Ukraine lags far behind the Project Management Salary in Switzerland, Germany, Netherlands, and other European Union countries. The main options for banking project implementation are systematized. It is established that for the successful implementation of any project in the bank, it is necessary to construct the effective system of remuneration for the project office. The classification of expenses in the framework of project implementation in banks is identified. It is proposed to structure the expenses in the framework of project implementation in banks into three groups: target costs, general project costs, general bank costs. The investigation results are presented in the form of tables and graphical interpretations. The options for successful implementation of banking project are revealed and several methods of the system of calculating remuneration in the form of incentives are highlighted. In order to stimulate project participants during its life cycle, the relevance of applying a piece-rate bonus system of remuneration in bank project management is substantiated. Two versions of the organization of salary payment in piece-rate bonus system of remuneration depending on the duration of the bank project are proposed. The features of accounting for payroll settlements with personnel in project banking management are highlighted, and accounting entries related to the formation of accounting information about settlements arising between project participants in banks are provided in this paper. A number of recommendations for the development of project banking management are developed.

Key words: bank, accounting, project implementation, salary, remuneration system.

https://doi.org/10.33108/galicianvisnyk_tntu2021.01.077

Received 03.03.2021

Постановка проблеми. Однією з головних функцій проектного менеджменту є функція управління командою проекту, яка полягає у визначенні кваліфікаційного складу учасників проекту, мотивації й системи оплати праці проектної команди.

В умовах упровадження нових продуктів та послуг у банківських установах оплата праці учасників проекту $є$ одним 3 найважливіших аспектів банківського менеджменту. У системі бухгалтерського обліку питання, пов'язані з нарахуванням та виплатою заробітної плати учасникам проекту, є одними з найважливіших аспектів. На даній ділянці бухгалтерського обліку знаходить відображення особистий внесок кожного учасника проекту в кінцеві результати відповідно до якого здійснюється їх оплата праці.

В умовах розроблення та реалізації проектів оплата праці базується на двох головних принципах - відносній свободі участі в проекті залучених фахівців та їх повній відповідальності за результати своєї діяльності. Тому дедалі гострішою постає проблема організації оплати плати учасників банківських проектів, яка має повністю залежати від ефективності роботи проектної команди та матеріально зацікавити іiї в кінцевих результатах проекту.

Аналіз останніх досліджень і публікацій. Застосування проектного менеджменту поширене як в державному секторі, так і серед комерційних організацій. Найбільша затребуваність в даному методі управління спостерігається в банківських установах, так як сприяє координації робіт 3 різних напрямків, пов'язаних 3 технологічним розвитком банків, а також розробленням і впровадженням нових технологій, продуктів і послуг.

Загальні витрати проекту включають матеріальні витрати, амортизацію, витрати на оплату праці та інші витрати. Зазвичай витрати на оплату праці, які включають витрати на основну зарплату, додаткову зарплату та нарахування на зарплату складають найбільшу частку в витратах проекту, про що свідчить рівень середньої заробітної плати проектних менеджерів. Середня заробітна плата проектних менеджерів серед країн ЄС наведена в таблиці 1. 
Таблиця 1. Огляд зарплати в рамках управління проектами у 2019 році

Table 1. Project Management Salary Review in 2019

\begin{tabular}{|c|c|c|c|}
\hline № & Країна & Кількість респондентів, чол. & Середня заробітна плата, дол. США \\
\hline 1 & Switzerland & 539 & 132,086 \\
\hline 2 & Germany & 988 & 96,987 \\
\hline 3 & Netherlands & 347 & 93,839 \\
\hline 4 & Belgium & 243 & 92,352 \\
\hline 5 & Ireland & 520 & 85,829 \\
\hline 6 & Sweden & 463 & 72,759 \\
\hline 7 & France & 792 & 68,663 \\
\hline 8 & Italy & 1,131 & 57,219 \\
\hline 9 & Spain & 1,308 & 52,642 \\
\hline 10 & Poland & 470 & 47,841 \\
\hline 11 & Portugal & 340 & 45,775 \\
\hline
\end{tabular}

Джерело: складено авторами за даними [1]

Таким чином, середня заробітна плата (при перерахунку на долари США за звичайними курсами обміну) значно варіюється у професіоналів проекту від країни до країни. Країнами $Є С$, де фахівці проектів повідомляють про найвищі середні зарплати, $\epsilon$ Швейцарія (132 086 доларів США), Німеччина (96,987 доларів США), тоді як країнами, що мають найнижчі середні зарплати, є Польща (47,841 доларів США) та Португалія (45,775 доларів США).

Згідно 3 дослідженнями інформаційного порталу ua.trud.com середній рівень заробітної плати проектних менеджерів в Україні значно відрізняється від європейського, про що свідчить дані рисунка 1.

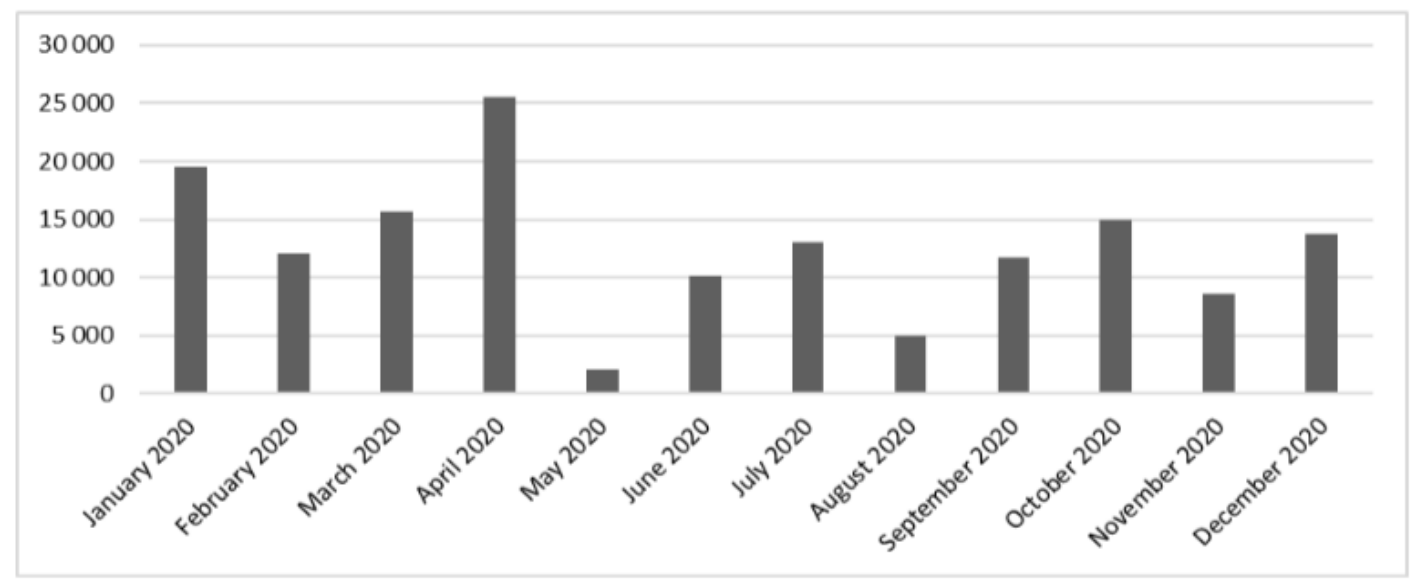

Рисунок 1. Рівень середньої зарплатні «Менеджер проектів в Україні»

Figure 1. Average salary level of «Project manager in Ukraine»

Джерело: складено авторами за даними [2]

Таким чином, за європейськими стандартами середня заробітна плата менеджера проектів в Україні значно менша, має значні коливання протягом періоду та за підсумками 2020 року складає в середньому 12639 грн або менше ніж 450 доларів США.

Мета дослідження полягає в узагальненні сучасних теоретичних та практичних методів і підходів організації й методики обліку та аналізу оплати праці учасників проектної команди в банках та виробленні рекомендацій щодо створення ефективної 
системи оплати праці учасників проекту, яка б мала чіткий і очевидний поділ на всіх етапах банківського проектного менеджменту.

Постановка завдання. Завданнями даної роботи є дослідження питань організації та обліку оплати праці проектної команди; узагальнення сучасних практик банківського проектного менеджменту; вироблення рекомендацій щодо створення ефективної системи оплати праці учасників проекту в банках на основі виявлення вузьких місць даних процесів. Для вирішення поставлених завдань використано такі методи: аналізу та синтезу, соціологічного дослідження, узагальнення, системний підхід.

Виклад основного матеріалу. Фінансування банківського проекту в одному випадку може повністю покрити витрати на оплату праці за рахунок проекту, а в іншому випадку замовники проекту можуть встановлювати різні обмеження на рівень заробітної плати проектної команди у відсотках до загальної вартості проекту.

На етапі моніторингу й оцінювання команди проекту здійснюється аналіз наявності відхилень між запланованими й фактичними витратами, при цьому проектний менеджер повинен вживати відповідні заходи для коригування та контролю затрат, щоб не допустити ризику недостачі фінансування до закінчення проекту.

Наприкінці банківського проекту розробляється, як правило, звіт про його реалізацію. Такий звіт отримує замовник проекту. Копії проектного звіту отримують члени проектної команди i менеджер проекту. Звіт $\epsilon$ основою для фінансового розрахунку з окремими учасниками проектної команди, особливо коли вони співпрацюють у рамках тимчасового контракту з іншими компаніями або організаціями.

Для успішної реалізації банківського проекту, проектна команди повинна вирішувати завдання за визначений проміжок часу i за допомогою встановленого фінансового бюджету. Проблеми найчастіше виникають у сфері проектування завдання проекту, коли здійснюється розрахунок сукупної заробітної плати, розрахунок чистої заробітної плати та розрахунок усіх видів відрахувань.

На практиці використовують кілька варіантів створення проектної команди. Найпоширеніші варіанти реалізації банківського проекту представлено на рисунку 2.

\begin{tabular}{|c|c|c|}
\hline Варіант 1 & Варіант 2 & Варіант 3 \\
\hline $\begin{array}{c}\text { Створення команди проекту на } \\
\text { чолі з менеджером проекту для } \\
\text { координації діяльності } \\
\text { учасників проектної команди }\end{array}$ & $\begin{array}{c}\text { Створення команди проекту } \\
\text { під керівництвом } \\
\text { працюючого менеджера } \\
\text { проекту }\end{array}$ & $\begin{array}{c}\text { Створення проектної команди } \\
\text { разом з керівником, якщо } \\
\text { термінове замовлення й проект має } \\
\text { бути готовий протягом одного } \\
\text { місяця }\end{array}$ \\
\hline $\begin{array}{c}\text { Проектний час = потреба на час } \\
\text { : кількість учасників } \\
2 \text { та } 1 / 2 \text { місяця = } 10 \text { людино- } \\
\text { місяців : } 3 \text { учасник }+1 \\
\text { менеджер } \\
\end{array}$ & $\begin{array}{c}\text { Проектний час = потреба на } \\
\text { час : кількість спеціалістів } \\
3 \text { та } 1 / 3 \text { місяця = } 10 \text { людино- } \\
\text { місяців : } 3 \text { учасникам }\end{array}$ & $\begin{array}{c}\text { Кількість спеціалістів = потреба на } \\
\text { час : проектний час } \\
?=10 \text { людино-місяців : } 1 \text { місяць } \\
1 \text { менеджер }+9 \text { учасників }\end{array}$ \\
\hline
\end{tabular}

Рисунок 2. Варіанти реалізації банківського проекту

Figure 2. Options for banking project implementation

Джерело: складено авторами за даними $[4,7,9]$.

Виконавець проекту узгоджує з замовником банківського проекту зручний варіант створення команди проекту на чолі з менеджером проекту, під керівництвом працюючого менеджера проекту або створення проектної команди разом з керівником. Вибір варіанта реалізації банківського проекту суттєво впливає на проектний час, кількість учасників проекту, форму оплати та мотивації. При виборі варіанта на чолі із менеджером проекту 
або під керівництвом працюючого менеджера проекту визначають три групи ключових показників проектного менеджера, які характеризують його ефективність:

- реалізація мети замовника (успішно виконане завдання, високий рівень задоволеності замовника якістю послуги/продукту);

- виконання мети замовника проекту (фінансовий показник);

- реалізація прагнень учасників проекту (оптимальна мотивація кар'єрного розвитку, привабливі умови фінансової винагороди, усунення/вирішення конфліктів, ефективна взаємодія).

3 метою ефективного оцінювання економічної сутності всіх реалізованих у рамках банківського проекту завдань та з урахуванням специфіки проектного підходу в загальній операційній діяльності банків, пропонується класифікація витрат у рамках проектів за трьома групами: цільові витрати, загально-проектні витрати, загально-банківські витрати.

Під цільовими слід розуміти витрати, призначені для виконання технічних, технологічних, операційних робіт, з чого випливає їх приналежність до реалізації фаз життєвого циклу банківського проекту, наприклад:

- оплата праці з нарахуваннями банківських фахівців, залучених для вивчення та попереднього оцінювання початкових даних на етапі визначення загальної концепції проекту та залучених для навчання й подальшого супроводження нових продуктів, послуг, процесів на кінцевому етапі впровадження проекту;

- програмне забезпечення, комп'ютерна техніка, матеріали, необхідні для реалізації технічної або технологічної складової проекту;

- послуги сторонніх організацій;

- інші витрати, що безпосередньо впливають на виконання поставлених цілей проекту.

Під загально-проектними слід розуміти витрати, спрямовані на здійснення управління банківським проектом, які були понесені в рамках стадій управління проектом. До загально-проектних витрат можна віднести:

- оплату праці з нарахуваннями менеджера проекту;

- оплату праці з нарахуваннями команди проекту;

- програмне забезпечення;

- матеріали;

- інші витрати, необхідні для реалізації управлінських рішень [4].

Загально-банківські включають у себе витрати, пов'язані 3 організацією та підтриманням загального функціонування банківського проекту. До них можна віднести вартість основних засобів, оренду будівлі офісу, комунальні платежі, послуги зв'язку та інші відповідно до особливостей упровадження проекту в банку. Методику класифікації витрат у банківських проектах наведено в таблиці 2.

Таблиця 2. Класифікація витрат у рамках упровадження проектів у банках

Table 2. Classification of expenses in the framework of project implementation in banks

\begin{tabular}{|c|c|c|c|c|c|c|c|c|c|}
\hline \multicolumn{4}{|c|}{ Технологічні } & Загально-банківські & \multicolumn{5}{|c|}{ Управлінські } \\
\hline \multicolumn{4}{|c|}{ Фази життєвого циклу банківського проекту } & & \multicolumn{5}{|c|}{ Стадії управління проектом у банку } \\
\hline 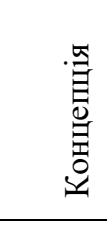 & 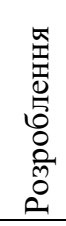 & 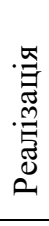 & 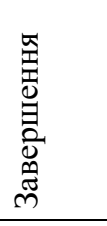 & & 哥 & 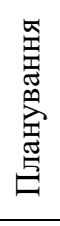 & 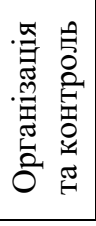 & 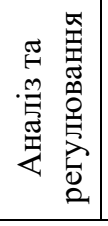 & 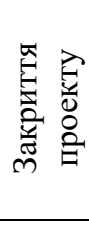 \\
\hline \multicolumn{4}{|c|}{ Цільові витрати } & & \multicolumn{5}{|c|}{ Загально-проектні витрати } \\
\hline \multicolumn{4}{|c|}{ Статті витрат } & Статті витрат & \multicolumn{5}{|c|}{ Статті витрат } \\
\hline
\end{tabular}

Джерело: складено авторами за даними [3-9]. 
Вважаємо, що наведена методика класифікації витрат у процесі впровадження проектів у банківській діяльності, яка дозволить не тільки найбільш точно визначати статті витрат у рамках банківських проектів, але й проводити управлінський аналіз у частині здійснених витрат банківського проекту.

Таблиця наочно демонструє розподіл витрат на цільові витрати, загально-проектні витрати, загально-банківські витрати в рамках банківських проектів. Однак слід позначити ще один рівень класифікації - статті витрат, які передбачають угруповання однорідних витрат відповідно до економічної спрямованості банківського проекту.

Розподіл усіх понесених витрат на цілі управління й реалізацію банківських проектів дозволить зробити процедуру оцінювання витрат найпрозорішою. Варто зазначити, що наведена систематизація витрат носить рекомендаційний характер i передбачає можливість адаптації до специфіки діяльності окремо взятих проектів, що реалізуються в банках та фінансових установах.

На даний момент у банківській системі координація роботи з різних напрямків, пов'язаних з технологічним розвитком банків, а також розробленням і впровадженням нових технологій, продуктів і послуг побудована на проектному підході, відповідно перед керівниками проектів стоїть важливе питання, як вибудувати ефективну систему оплати праці, в якій би враховувався внесок кожного учасника проекту.

3 огляду на специфіку системи мотивації діяльності учасників банківського проекту, матеріальне стимулювання проектної команди можливе через використання певних адаптованих модифікацій відрядної або погодинної оплати праці.

Зауважимо, що хоча терміни часто згадуються як синоніми, поняття «оплата праці» має набагато ширше й об'ємніше тлумачення в порівнянні $з$ терміном «заробітна плата». Оплата праці включає в себе не тільки саму систему винагороди за працю, а й усю сукупність відносин, що знаходяться між учасниками банківського проекту, як то режими, системи і форми оплати праці, правила документального оформлення використання робочого часу і трудовитрат, терміни виплати заробітної плати тощо [5].

На практиці двома базовими системами оплати є тарифна, призначена для диференціювання оплати праці за категоріями учасників проекту, які виконують завдання різної складності, та безтарифна, заснована на повній залежності заробітку учасника проекту від кінцевих результатів роботи проектної команди та оцінювання вкладу кожного учасника проекту.

Існує кілька форм оплати праці. Замовник банківського проекту самостійно вибирає для своєї діяльності зручну форму оплати, причому в одному проекті у різних учасників проектної команди може бути різна форма оплати їх праці. Загальна схема форм оплати праці представлена на рисунку 2.

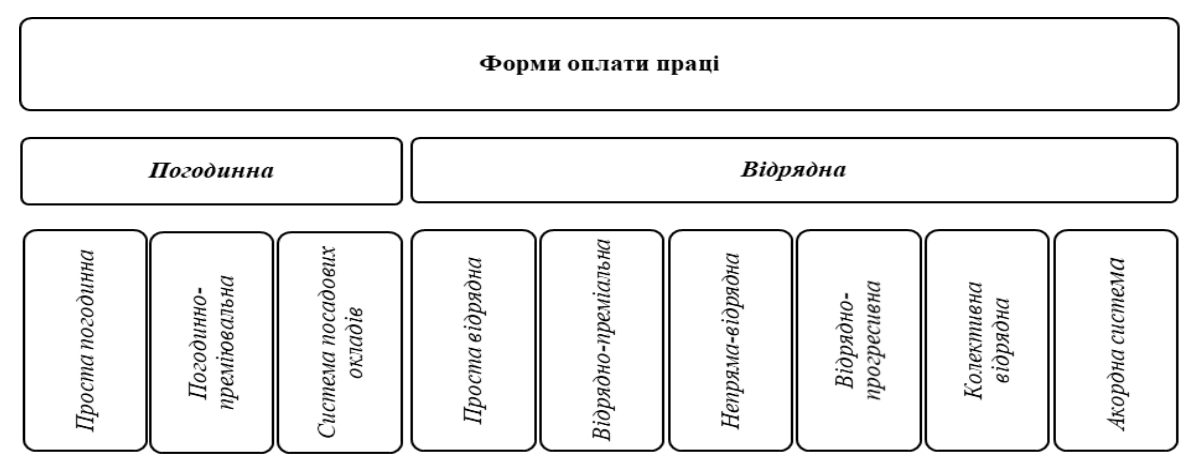

Рисунок 3. Форми оплати праці

Figure 3. Forms of remuneration

Джерело: складено авторами за даними [6]. 
Слід зазначити, що в даний момент немає якогось певного й однозначного підходу до формування системи оплати учасників банківського проекту. Разом 3 цим, багато економістів і управлінців висловлюють думку, що комбінована форма оплати праці найбільш відповідає особливостям оплати праці в проектному менеджменті. Ключовим параметром вибору форм оплати праці та комбінації їх пропорцій $\epsilon$ співвідношення базової та змінної частин оплати праці, яка варіюється залежно від організації, планування й координації використання людських і фінансових ресурсів протягом усього життєвого циклу проекту [7].

Враховуючи вищезазначене, вважаємо, що в банківському проектному менеджменті найкраще застосовувати акордно-преміальну систему оплати праці. Акордна система оплати праці - це різновид відрядної, оплати праці, сутність якої полягає в тому, що розмір оплати праці встановлюється на весь обсяг виконання робіт із визначенням терміну його виконання, що в принципі відповідає сутності проектного менеджменту. На практиці промислових підприємств акордна система оплати праці застосовується в таких випадках:

- підприємство не укладається в термін із виконанням якогось замовлення, і при його невиконанні воно буде зобов'язане заплатити значні суми штрафних санкцій у зв'язку з умовами договору;

- при надзвичайних обставинах (пожежі, обвали, виходи 3 ладу основної технологічної лінії по серйозній причині), що призведуть до припинення виробництва;

- при гострій виробничій необхідності виконання окремих робіт або впровадженні нового обладнання на підприємстві.

Зауважимо, що перший і третій варіанти відображають основи організації проектного менеджменту в банках, для якого притаманне впровадження певного проекту задля необхідності впровадження нових банківських технологій, продуктів і послуг банків та при несвоєчасному невиконанні якого виникають зобов'язання щодо виплати значних сум штрафних санкцій відповідно до договірних умов.

Акордно-преміальна система оплати праці передбачає співвідношення базової та змінної частини оплати праці, яка виплачується за термінове або якісне виконання етапів чи певних завдань у рамках проекту, що підсилює стимулювання учасників проекту протягом усього його життєвого циклу. В вищезазначеній системі оплати праці доцільно застосовувати такі два варіанти організації оплати праці [8]:

1) у невеликих за тривалістю проектах (наприклад, проект на основі термінового замовлення, який має бути готовий протягом одного місяця), учасників заохочують на виконання проекту в термін;

2) у проектах тривалістю понад шість місяців учасників заохочують на виконання проекту якісно та в термін у формі погодинної оплати праці за складною системою.

За першою системою оплати праці учасників проекту загальна винагорода становить $100 \%$, при цьому на етапі визначення планового та освоєного обсягу запланованих робіт учасникам виплачується аванс $20 \%$ від загальної суми, $30 \%$ - за другий етап, коли визначається фактична вартість виконаних робіт, та за бюджет завершення всього проекту - інші 50\% [9].

Операції нарахування заробітної плати з додатковою оплатою у вигляді системи винагороди учасника та менеджера проекту за першою системою оплати праці наведено в таблиці 3. 
Таблиця 3. Відображення в обліку операцій по нарахуванню винагород в рамках проекту за першим варіантом організації оплати праці

Table 3. Reflection in the accounting of operations on accrual of remunerations within the project underthe first version of remuneration organization

\begin{tabular}{|c|l|c|c|}
\hline Винагорода (\%) & \multicolumn{1}{|c|}{ Зміст операції } & Д-т & К-т \\
\hline $20 \%$ & Нарахування оплати праці учасникам проекту, 1 етап & 7400 & 3551 \\
\hline $20 \%$ & Нарахування оплати праці Менеджер проекту, 1 етап & 7409 & 3551 \\
\hline $30 \%$ & Нарахування оплати праці учасникам проекту, 2 етап & 7400 & 3652 \\
\hline $30 \%$ & Нарахування оплати праці Менеджер проекту, 2 етап & 7409 & 3652 \\
\hline До 50\% & $\begin{array}{l}\text { Додаткові премії, заохочення учасникам та Менеджеру } \\
\text { проекту відповідно до результатів, 6 етап }\end{array}$ & 7403 & 3652,3659 \\
\hline
\end{tabular}

Джерело: складено авторами за даними $[3,8,9,10]$.

За другою системою оплати праці учасників проекту система винагороди виплачується у формі погодинної оплати праці за складною системою й обліковується таким способом, як нарахування заробітної плати, до якої прив'язані конкретні досягнення учасника проектної команди, які підкреслюють його цінність для проекту. Також враховується тарифна система, яка являє собою сукупність нормативів, що регулюють рівень заробітної плати залежно від різних факторів: складність банківського проекту; інтенсивність праці учасників проекту; характер завдань проектної команди.

Таким чином, за другою системою оплати праці учасників проекту загальна винагорода становить $100 \%$, при цьому, наприклад, на кожному 3 п’яти етапів банківського проекту відповідно до визначення планового та освоєного обсягу запланованих робіт учасникам виплачується $10 \%$ від загальної суми та $5 \%$ виплати (премії, заохочення) відповідно до результатів виконання етапу проекту. За заключний етап, коли визначається бюджет завершення всього проекту - інші $15 \%$ від загальної суми та $10 \%$ премії, заохочення.

Операції нарахування заробітної плати з додатковою оплатою у вигляді системи винагороди, учасників та менеджера проекту за другою системою оплати праці наведено в таблиці 4.

Таблиця 4. Відображення в обліку операцій з нарахування винагород у рамках проекту за другим варіантом організації оплати праці

Table 4. Reflection in the accounting of operations on accrual of remunerations within the project under the second version of remuneration organization

\begin{tabular}{|c|l|c|c|}
\hline Винагорода (\%) & \multicolumn{1}{|c|}{ Зміст операції } & Д-т & К-т \\
\hline $10 \%$ & Нарахування оплати праці учасникам проекту, 1-5 етап & 7400 & 3652 \\
\hline До 5\% & $\begin{array}{l}\text { Додаткові премії, заохочення учасникам проекту відповідно } \\
\text { до результатів 1-5 етап }\end{array}$ & 7400 & 3659 \\
\hline $10 \%$ & Нарахування оплати праці Менеджер проекту, 1-5 етап & 7409 & 3652 \\
\hline До 5\% & $\begin{array}{l}\text { Додаткові премії, заохочення Менеджеру проекту відповідно } \\
\text { до результатів, 1-5 етап }\end{array}$ & 7409 & 3659 \\
\hline $15 \%$ & Нарахування оплати праці учасникам проекту 6 етап & 7400 & 3652 \\
\hline До 10\% & $\begin{array}{l}\text { Додаткові премії, заохочення учасникам проекту відповідно } \\
\text { до результатів, 6 етап }\end{array}$ & 7400 & 3659 \\
\hline $15 \%$ & Нарахування оплати праці Менеджер проекту, 6 етап & 7409 & 3652 \\
\hline До 10\% & $\begin{array}{l}\text { Додаткові премії, заохочення Менеджеру проекту відповідно } \\
\text { до результатів, 6 етап }\end{array}$ & 7409 & 3659 \\
\hline
\end{tabular}

Джерело: складено авторами за даними [3, 8, 9, 10]. 
Висновки. Практичне значення та цінність отриманих результатів дослідження полягає в обгрунтуванні напрямів удосконалення організації й методики обліку та аналізу оплати праці учасників проектної команди в банках. Застосування вищезазначених рекомендацій у проектній діяльності банківських установ сприятиме посиленню достовірності облікових даних та розширенню інформативності аналізу виконання проекту як необхідної умови забезпечення раціонального використання грошових ресурсів банку в рамках фінансування банківських проектів.

Отже, питання оплати праці та мотивації учасників проекту не можна вважати чимось незвичайним або неприродним - без них не обходиться жоден проект у банку. Однак уміння правильно визначити систему оплати праці, виявити фактори мотивації, усунути можливі ризики перевитрат і є основною перевагою ефективного проектного менеджменту в банківських установах.

Conclusions. Practical significance and value of the obtained investigation results are to substantiate the directions for improving the organization and methodology of accounting and analysis of remuneration of project team participants in banks. The application of the above mentioned recommendations in the practical activities of banking institutions facilitates strengthening of accounting data reliability, expands the information content of project performance analysis as a necessary condition for ensuring the rational use of the bank's monetary resources in the framework of financing banking projects.

Hence, the problem of remuneration and motivation of project participants cannot be considered as something unusual or unnatural - no project in the bank can work without them, but the ability to determine correctly the remuneration system, to identify motivation factors, to eliminate possible risks of overspending is the main advantage of effective project management in banking institutions.

\section{Список використаної літератури}

1. Earning Power Project Management Salary Survey Eleventh Edition. URL: https://www.pmi.org/ learning/careers/project-management-salary-survey (дата звернення: 08.01.2021).

2. Рівень середньої зарплатні за останні 12 місяців: «Менеджер проектів в Україні». URL: https://ua. trud.com/ua/salary/2/78027.html (дата звернення: 08.01.2021).

3. Цятковська О. В. Фінансовий облік розрахунків з працівниками банків: актуальні питання. Глобальні та національні проблеми економіки. 2015. Вип. 6. С. 901-905. URL: http://global-national.in.ua/issue-62015/14-vipusk-6-lipen-2015-r/1155-tsyatkovska-o-v-finansovij-oblik-rozrakhunkiv-z-pratsivnikami-bankiv -aktualni-pitannya (дата звернення: 08.01.2021).

4. Лукина А. О. Управление проектами. Проблемы науки. 2019. Вип. 1 (37). С. 53-57.

5. Методы и принципы правового регулирования заработной платы. Трудовое право. URL: http://uristinfo.net/trudovoe-pravo/220-kurstrudovogo-prava-ii-t-lushnikov-lushnikova/5519-zarabotnajaplata.html?start=2. (дата звернення: 08.01.2021).

6. Закон України Про оплату праці. 2020. URL: https://zakon.rada.gov.ua/laws/show/108/95-\%D0\%B2\% D1\%80\#Text (дата звернення: 08.01.2020).

7. Mark H. The Effective Manager. 2017. URL: https://docplayer.ru/184113746-Mark-horstman-theeffective-manager.html (дата звернення: 08.01.2021).

8. Бикова А. Л. Сучасні системи винагороди працівників: вітчизняний та зарубіжний досвід. Економічні науки. 2016. URL: http://molodyvcheny.in.ua/files/journal/2016/10/75.pdf (дата звернення: 08.01.2021).

9. Suruchanu A., Soboleva-Tereshchenko E. Features Of Financing And Payment In The Field Of Project Management. Science and Technolog. Abstracts of the 8th International scientific and practical conference. Nika Publishin. Manchester, Great Britain. 2020. P. 39-43. URL: http://el-conf.com.ua/(дата звернення: 08.01.2021).

10. Соболєва-Терещенко О. А., Жарнікова В. В. Особливості бухгалтерського обліку розрахунків 3 покупцями в умовах застосування програм лояльності. Науковий вісник Ужгородського університету. Серія: Економіка. 2017. Вип. 2 (50). С. 325-332. URL: https://dspace.uzhnu.edu.ua/ jspui/handle/lib/18221 (дата звернення: 08.01.2021) 


\section{References}

1. Earning Power Projects Management Salary Survey Eleventh Edition. Available at: https://www.pmi.org/ learning/tsareers/projetst-management-salary-survey (accessed 08.01.2021). [In English].

2. Riven' seredn'oyi zarplatni za ostanni 12 misyatsiv: "Menedzher proektiv v Ukrayini". Available at: https://ua.trud.tsom/ua/salary/2/78027.html (accessed 08.01.2021). [In Ukrainian].

3. Tsyatkovs'ka O. V. Finansovyy oblik rozrakhunkiv z pratsivnykamy bankiv: aktual'ni pytannya. Global and national economic problems. Vypusk 6. 2015. P. 901-905. Available at: http://global-national.in.ua/ archive/6-2015/06_2015.pdf (accessed 08.01.2021). [In Ukrainian].

4. Lukyna A. O. Upravlenye proektamy. Problemb nauky. 2019. 1 (37). Available at: https://cyberleninka. ru/article/n/upravlenie-proektami-2/viewer (accessed 08.01.2021). [In Russian].

5. Metody y pryntsypy pravovoho rehulyrovanyya zarabotnoy platy. Available at: URL:http://uristinfo.net/ trudovoe-pravo/220-kurstrudovogo-prava-ii-t-lushnikov-lushnikova/5519-zarabotnaja-plata.html?start=2. (accessed 08.01.2021). [In Ukrainian].

6. Zakon Ukrayiny "Pro oplatu pratsi". Available at: https://zakon.rada.gov.ua/laws/show/108/95-\%D0\%B2 \%D1\%80\#Text. (accessed 08.01.2021). [In Ukrainian].

7. Mark H. The Effetstive Manager. 2017. Available at: https://dotsplayer.ru/184113746-Mark-horstman-theeffetstive-manager.html. (accessed 08.01.2021). [In English]

8. Bykova A. L. Suchasni systemy vynahorody pratsivnykiv: vitchyznyanyy ta zarubizhnyy dosvid. 2016. Available at: http://molodyvcheny.in.ua/files/journal/2016/10/75.pdf. (accessed 08.01.2021) [In Ukrainian]

9. Suruchanu A., Soboleva-Tereshchenko E. Features of Financing and Payment in The Field of Project Management. Science and Technolog. Abstracts of the 8th International scientific and practical conference. Nika Publishin. Manchester, Great Britain. 2020. P. 39-43. [In English].

10. SobolievaTereshchenko O., Zharnikova V. Features of accounting settlements with customers in conditions of application of loyalty programs. Scientific Bulletin of Uzhhorod National University Series: Economics. 2017. 2(50). P. 325-332. Available at: https://dspace.uzhnu.edu.ua/jspui/handle/lib/18221 (accessed 08.01.2021). [In Ukrainian]. 